\title{
O inquérito sobre a experiência
}

José Feres Sabino ${ }^{1}$

Resumo: Este texto, movido pela ideia de inquérito da experiência, percorre a obra do escritor argentino Ricardo Piglia, desde suas primeiras publicações até o romance Alvo Noturno, a fim de mostrar que o tema da experiência, ou da crise da experiência, é elemento fundamental da própria construção narrativa de sua obra. A partir desse elemento, os conceitos de narrador, narração, ficção e história são reposicionados.

Palavras-chave: Ricardo Piglia - experiência - narrador - Emilio Renzi - ficção história-memória.

Abstract: This text, led by the experience inquiry idea, travels through the work of the Argentinean writer Ricardo Piglia, from his first publications to this novel Nocturnal Target, in order to show that the experience theme, or the experience crisis, is an essential element of his work own narration development. From this element, the narrator, narration, fiction and history concepts are repositioned.

Keywords: Ricardo Piglia - experience - narrator - Emilio Renzi - fiction - history memory.

1. Se a arte é uma forma sintética do universo, um microcosmo que reproduz a especificidade do mundo, tal como pensa o escritor Ricardo Piglia ao recordar uma frase de Claude Lévi-Strauss ("a realidade trabalha em escala real, ao passo que a arte trabalha em escala reduzida"), poderíamos então considerar não só a obra de um escritor como um microcosmo, mas também considerar parte dela - um trecho, um parágrafo, uma anotação - como uma semente que condensa em si o todo.

1 É tradutor, graduado em Filosofia pela Universidade de São Paulo (USP), com mestrado em Filosofia pela mesma instituição. 
Assim, numa anotação do diário do narrador da novela Prisão Perpétua, de Ricardo Piglia, construída com fragmentos da própria vida do escritor, estaria delimitado o núcleo poético em torno do qual gira a obra desse autor argentino:

A luz de Flaubert. O romance moderno é um romance carcerário. Narra o fim da experiência. E quando faltam experiências o relato caminha para a perfeição paranoica. $\mathrm{O}$ vazio é coberto com o tecido persecutório das ligações perfeitas, a estrutura fechada, le mot juste. Flaubert traça esse caminho, dizia Steve. Um homem trancado dias inteiros em sua cela de trabalho, isolado da vida, que constrói sob altíssima pressão a forma pura do romance. A luz laboriosa de seu quarto que permanecia acesa toda a noite servia de farol para os barcos que atravessavam o rio. Esses marinheiros, é claro, disse Steve, eram melhores narradores que Flaubert. Construíram o fluir manso do relato no rio da experiência. ${ }^{2}$

A imagem do rio da experiência e do quarto fechado retoma uma distinção proposta por Walter Benjamin em seu célebre ensaio "O narrador. Considerações sobre a obra de Nikolai Leskov" (1936). ${ }^{3}$ Nele, o filósofo alemão estabelece a distinção entre narrador e escritor (romancista) topologicamente: o narrador retira o que conta de sua própria experiência e da dos outros, ou seja, ele está imerso na vida, pertence ao âmbito dos acontecimentos que "produzem" a experiência, ele é, portanto, o marinheiro navegando no rio da vida, ao passo que o escritor, o romancista, está isolado da vida, está situado dentro do quarto, e por isso, o que o move é o "sentido da vida".

Essa dupla espacialidade - dentro da vida/isolado da vida - foi inaugurada no século XVIII, no ensaio Poesia Ingênua e Poesia Sentimental, do poeta e pensador alemão Friedrich Schiller, com a distinção de dois tipos de poeta que se baseia justamente no modo como este se relaciona com a natureza: se o poeta pertence à natureza, então é ingênuo; os que foram exilados dela, são os sentimentais. ${ }^{4}$

2 PIGLIA, R. Prisão perpétua. São Paulo: Iluminuras, 1989, pp. 23-4.

3 BENJAMIN, W. "O narrador. Considerações sobre a obra de Nikolai Leskov". In: Magia e técnica, arte e política. Obras Escolhidas, vol. 1. São Paulo: Brasiliense, 1987, pp. 201-2 e 212-3.

4 Schiller é citado por Benjamin no ensaio "O narrador. Considerações sobre a obra de Nikolai Leskov": "Já se foi a época, diz Leskov, em que o homem podia sentir-se em harmonia com a natureza. Schiller chamava essa época o tempo da literatura ingênua.". Idem, ibidem, p. 210. 
Embora possa soar descabida a remissão ao século XVIII, já que a datação que Piglia propõe para o fim da experiência é o século XIX (Flaubert como "historiador" da questão), no ensaio de Schiller aparece a ideia fundamental, presente tanto em Benjamin quanto em Piglia, da correlação entre pertencer a um lugar, ter experiências e poder narrar. A narrativa só se torna possível quando o narrador é parte de um todo e por isso capaz de ter experiências. No caso de Piglia, porém, além do afastamento da vida (isolamento, exílio), há também clausura: o escritor não se encontra apenas isolado da vida, mas também trancando em seu quarto. ${ }^{5}$

2. O primeiro gesto literário de Ricardo Piglia - e isso pode ser verificado em suas entrevistas, ou mesmo no relato "Prisão Perpétua" - está ligado à perda de sua cidade natal. ${ }^{6}$ Em 1957, seu pai decide abandonar, junto com a família, a cidade de Adrogué onde viviam, e se mudar para Mar del Plata. O motivo é político: em 1955, quando os militares depuseram o presidente Juan Domingo Perón, seu pai tinha saído em defesa do presidente e por isso ficara preso por quase um ano.

Foi então que o jovem, com a idade de dezesseis anos, não querendo abandonar o lugar onde nascera, pois "não podia conceber que fosse possível viver em outro lugar", começou a escrever um Diário "num dos quartos desmantelados". 7

$\mathrm{O}$ ato de escrever um Diário, que nasceu para negar a perda do lugar natal, para repelir a violência da política, acabou forjando um espaço intermediário entre a realidade histórico-política e a cidade natal perdida. Ao longo dos anos, à medida que o Diário é escrito, ele se torna o centro da escritura de Ricardo Piglia, a ponto de o autor chegar a afirmar que publicaria mais dois ou três livros só para legitimar a publicação futura desse Diário: “[...] estou convencido de que, se eu não tivesse começado a escrevê-lo naquela tarde, nunca teria escrito outra coisa. Publiquei três ou quatro livros e publicarei talvez mais alguns só para justificar essa escritura". ${ }^{8}$

5 Numa nota introdutória para a nova edição de Nombre Falso, segundo livro de Ricardo Piglia, publicado em 1975, ele diz que os relatos do livro foram escritos em diferentes épocas, mas sempre no mesmo lugar. Esse lugar era o apartamento situado à rua Sarmiento, em Buenos Aires, onde havia uma janela que dava para a rua. Ele acredita que o fato de ter escrito os relatos olhando de quando em quando pela janela dá ao livro certa unidade, "como se as histórias tivessem estado ali, do outro lado do vidro". PIGLIA, R. Nombre falso. Barcelona: Editorial Anagrama, 2002, p. 9.

6 PIGLIA, R. Crítica y Ficción. Buenos Aires: Seix Barral, 2000, pp. 59 e 99.

7 PIGLIA, Ricardo. Prisão perpétua. São Paulo: Iluminuras, 1989, p. 13. 
Uma das primeiras anotações que se lê no Diário do narrador do relato "Prisão Perpétua" é justamente a constatação do vazio:

[...] Gosto muito dos primeiros anos do meu Diário justamente porque ali luto contra o vazio total. Não acontecia nada, na realidade nunca acontece nada, mas naquele tempo isso me preocupava. Era muito ingênuo, estava todo o tempo procurando aventuras extraordinárias. Então comecei a roubar a experiência dos conhecidos, as histórias que eu imaginava que viviam quando não estavam comigo. ${ }^{9}$

Nesse trecho, seria um enorme equívoco atribuir a questão da falta de experiência à juventude do narrador. Ao contrário, desde cedo, a questão do fim da experiência aparece para Ricardo Piglia vinculada ao isolamento, à ausência de acontecimentos ou à sensação de não ter vivido algo que realmente foi vivido.

3. O escritor mexicano Juan Villoro ${ }^{10}$, num breve ensaio, assinalou que Ricardo Piglia, desde os seus primeiros relatos, encontrou na investigação um estímulo central para suas tramas. Levando em conta essa sugestão, somos induzidos a pensar que o Diário de Piglia é um imenso informe investigativo acerca do desaparecimento da experiência e do destino da narração.

Não só o narrador do Diário é transformado num investigador, mas praticamente todos os narradores de sua obra. O narrador passa a ser então uma espécie de detetive particular, cujo olhar ("private eye” designação em inglês para o detetive particular) define um tipo de narrador-leitor. "Uma das maiores representações modernas", escreve Piglia, "da figura do leitor é a do detetive particular (private eye) do gênero policial. E não me refiro à leitura alegórica (Sherlock Holmes lê pegadas no assoalho), mas ao ato de ler palavras impressas e decifrar signos escritos num papel)". ${ }^{11}$ Seja no diário, seja

8 Idem, ibidem, p. 13. Numa entrevista de 1982, Ricardo Piglia diz: "Esse diário para mim é a literatura, quero dizer que aí está, antes de mais nada, a história de minha relação com a linguagem. Eu escrevia para tentar saber o que era escrever: nisso (só nisso) já era um escritor. Esses cadernos se transformaram no laboratório da escrita [...]”, O laboratório do escritor, São Paulo: Iluminuras, 1994, p. 81.

9 PIGLIA, R. Prisão perpétua. São Paulo: Iluminuras, 1989, p. 14.

10 VILLORO, J. "Piglia, private eye", Letras Libres.

11 PIGLIA, R. O último leitor, São Paulo: Companhia das Letras, 2006, p. 74. 
nas narrativas, seja nos ensaios, a estratégia narrativa fundamental é sempre a mesma: leitura investigativa.

4. Ao inventariar as origens da literatura argentina, Piglia encontra na divisa "Deve-se ter um olho na inteligência francesa e o outro cravado nas entranhas da pátria”, de Esteban Echeverría, cujo conto "O matadouro" é o primeiro texto de ficção da literatura argentina, um olhar formativo estrábico:

A perspectiva estrábica é a verdadeira tradição nacional: a literatura argentina se constitui nessa dupla visão, nessa relação de diferença e aliança com outras práticas e outras línguas e outras tradições. Um olho é o aleph, o próprio Universo; o outro olho vê na sombra dos bárbaros o destino sul-americano. O olhar estrábico é assincrônico: um olho mira o passado, o outro está posto no que virá. ${ }^{12}$

"Perspectiva estrábica" ou "olhar vesgo" serve também para caracterizar o olhar de um de seus principais personagens, o jornalista e escritor em formação Emilio Renzi $^{13}$, alter ego do autor que, por exemplo, como narrador do romance Respiração artificial, planta um olho nas entranhas de sua família e de seu país e o outro na história e na cultura ocidentais. $\mathrm{O}$ aparecimento desse personagem em diversas obras não só reitera o núcleo poético da obra (o duplo inquérito: fim da experiência e destino da narração), mas também proporciona ao autor um lugar "dentro da obra":

a característica que Renzi tem, e que me parece muito útil, é que ele tem uma voz que sei como funciona. É como se eu tivesse um lugar

12 PIGLIA, R. "Sarmiento, escritor". In: Facundo ou civilização e barbárie. São Paulo: Cosac Naify, 2010, p. 15.

13 O nome completo de Ricardo Piglia é Ricardo Emilio Piglia Renzi. Emilio Renzi é, portanto, uma secção do nome do autor, que dá origem a um duplo uso: pseudônimo e personagem. Antes de aparecer como personagem nos textos de Piglia, Renzi, segundo Victor Pesce, já aparece como autor da tradução do texto "Estructuras significativas", de Lucien Goldman, em 1965 (ver "El problemático ejercicio del relato", nota 52. In: Jorge Lafforgue, Textos de y sobre Rodolfo Walsh, Alianza, 2000, p. 60). Em seu programa televisivo, na Argentina, Disparos en la biblioteca (El extraño caso del señor Renzi), Juan Sasturian conta que Piglia, em 1969, fundou e dirigiu uma coleção de literatura policial (Serie Negra) para a editora Tiempo Contemporaneo, de Buenos Aires. No primeiro volume da coleção, Cuentos policiales de Serie Negra, Emilio Renzi não só seleciona os autores como também assina a introdução do livro e as notas biográficas. 
no livro, alguém que posso imaginar com clareza, conhecer qual é sua visão dos acontecimentos, que perspectiva vai dar dos fatos. ${ }^{14}$

5. O "nascimento" de Emilio Renzi se dá no conto "A invasão", que compõe e intitula o primeiro livro de Piglia, publicado em 1967, e que começa assim: "Com o golpe do trinco ele os pressentiu atrás, no fundo da cela." Ao longo da leitura, descobrimos que o pronome "ele" se refere ao estudante Renzi, que acaba de ser preso. Na cela se encontram mais dois homens: “[...] um deles em pé, sem tocar a parede, como equilibrando-se e não vestido de todo; o outro, um moreno de óculos, deitado no chão". Os dois foram parar no xadrez por deserção, e Renzi ao ser perguntado pelo preso mais alto qual era o motivo de sua prisão, responde:

- Por causa de um rolo com o 'bode' Pelliza. Ele tem cisma comigo porque sou estudante e além disso... ${ }^{15}$

A descrição que o narrador faz da vestimenta de Renzi ("Lá fora tinham tirado seu cinto e o cordão de seus coturnos") indica que o estudante está possivelmente fazendo o serviço militar obrigatório e talvez tenha ocorrido algum desentendimento com seu superior.

Dentro de uma cela quente, pequena, de chão sebento, onde come, defeca e dorme, com mais dois homens, que, pelo menos ali, mantêm uma relação homoerótica, Renzi, ao adentrar aquele espaço, é imediatamente rechaçado:

- Escuta aqui, meu querido - disse -. É bom você não bancar o machinho aqui dentro, está me entendendo? Isto aqui não é universidade; por isso é melhor você ficar sentadinho aí e não encher o saco.

No conto, o jovem Renzi aparece alocado numa fronteira imaginária: cruzou a porta que separa a sociedade da criminalidade e, no entanto, na cela, é também afastado por aqueles que "pertencem" à marginalidade. Ele não pertence mais à sociedade, mas

14 Entrevista, Letras Libres, março de 2011, p. 71.

15 PIGLIA, R. A invasão. São Paulo: Iluminuras, 1997, p. 105. 
também não faz parte da criminalidade. Será justamente nesse espaço intermediário entre o mundo da lei e o mundo do crime que Renzi passará a transitar.

O gênero policial situa o detetive particular exatamente nesse lugar: não pertence nem ao mundo do crime, nem ao mundo da lei. ${ }^{16} \mathrm{E}$ o que faculta ao detetive a investigação é não ter nenhuma relação com as instituições. ${ }^{17}$ "O detetive", escreve Piglia, "é aquele que encarna o processo da narração como um trânsito do não saber ao saber". 18

Mesmo ainda não sendo um escritor, nem figurar como narrador nas histórias em que aparece (só o é de uma das partes do romance Respiração artificial), Renzi mantém sempre a mesma postura. No romance Dinheiro queimado, por exemplo, ainda estudante universitário, ele é enviado como correspondente do jornal El Mundo, de Buenos Aires, a San Fernando, província Buenos Aires, para cobrir um assalto a banco. $\mathrm{O}$ bando de assaltantes acaba se refugiando posteriormente em Montevidéu.

Num dos diálogos que trava com o delegado que investiga o caso, este lhe pergunta se ele tem filhos ou é casado, e Renzi responde que não, que não tem filhos e vive sozinho no Hotel Almagro. "Sou estudante" diz Renzi, "e ganho a vida como jornalista, como o senhor ganha como agente de polícia, e se faço perguntas é porque quero escrever uma reportagem veraz sobre o que está acontecendo". ${ }^{19}$ Um pouco antes de travarem esse diálogo, o delegado havia olhado para Renzi e pensado "outra vez esse fedelho desrespeitoso, de oclinhos e cabelo encaracolado, com cara de pateta, alheio ao clima real e ao perigo da situação, que parecia um paraquedista, ...". ${ }^{20}$

6. No romance Alvo Noturno, o jornalista Renzi é o enviado especial do jornal $E l$ Mundo para fazer uma matéria sobre o misterioso assassinato de Tony Durán, um porto-

16 Idem, ibidem. Formas breves. Barcelona: Editorial Anagrama, 2000, p. 66.

17 Idem. La ficción paranoica. Emilio Renzi aparece praticamente em toda obra de Ricardo Piglia. Nos romances, ele aparece em todos e a cronologia da publicação dos livros não obedece ao desenvolvimento do personagem. Indico a seguir a cronologia do personagem e a data de publicação dos livros: Dinheiro Queimado (1997), Alvo Noturno (2010), Respiração Artificial (1980) e A cidade ausente (1992).

18 Idem, ibidem.

19 PIGLIA, R. Dinheiro queimado. São Paulo: Companhia das Letras, 1998, p. 142.

20 Idem, ibidem, p. 140. No conto "O fim da viagem", com a morte do pai, que vive em Mar del Plata, Emilio Renzi viaja até lá. No ônibus, durante um diálogo com uma mulher, ela lhe pergunta qual é sua profissão: "Sou jornalista", ele responde. Entusiasmada, ela acrescenta: "Não me diga que faz reportagem policial." "Infelizmente só faço crítica de livros", diz ele. PIGLIA, R. O laboratório do escritor. São Paulo: Iluminuras, 1994, p. 16. 
riquenho que desembarca no pampa argentino portando uma mala de dinheiro. A investigação está a cargo do delegado Croce e de seu ajudante Saldías. Renzi acompanha as investigações ao lado dos dois ao mesmo tempo em que tenta “reconstruir" a história da família Belladona, que não só está ligada aos primórdios da fundação do povoado do pampa e ao processo de modernização da região, como também de algum modo parece estar envolvida com a morte do porto-riquenho, juntamente com outros figurões do local, por causa da construção de uma fábrica automotiva.

Num informe do secretário particular de Luca Belladona - que após a falência da fábrica de automóveis que erguera junto com seu irmão passara a viver trancado dentro dos escombros da fábrica - podemos destacar uma datação para a crise da experiência: ${ }^{21}$

Mais irreal era a economia, e mais ilusória. Sofrera um choque ao ver que o anúncio - do presidente dos Estados Unidos, Richard Nixon, no domingo 15 de agosto de 1971 à noite - do fim da convertibilidade do dólar em ouro, fim do Padrão Câmbio Ouro (ou Gold Exchange Standard) criado pela Conferência de Gênova em 1922. [...] A partir daquele momento tudo tinha virado, segundo Luca, "uma desgraceira" e - estivera pensando - em breve a especulação financeira começaria a predominar sobre a produção material. Os banqueiros imporiam suas normas e as operações abstratas dominariam a economia. ${ }^{22}$

O fim do padrão-ouro inaugura a época do destacamento da especulação financeira em relação à produção material: as finanças agora definem o âmbito das operações abstratas. A moeda deixa de ser unidade de conta para se transformar em mercadoria, ou seja, aquilo que seria o instrumento de compra é o elemento a ser comprado. Essa convertibilidade nos mostra que o mesmo raciocínio poderia ser aplicado à língua: ela se descasa da experiência e passa a operar única e exclusivamente no âmbito da abstração.

Traduzida em termos literários, temos uma crise da experiência de segundo grau. Agora não só a narrativa perde o lastro da experiência (o narrador é exilado), mas

21 A epígrafe do romance Alvo noturno é: "A experiência é uma lanterna que só ilumina quem a leva." Louis-Ferdinand Céline.

22 PIGLIA, R. Alvo noturno. São Paulo: Companhia das Letras, 2011, p. 200. 
também a língua (assim como a moeda) se converte em unidade autorreferente. Repetese em linguagem econômica a mesma polaridade apresentada na imagem do rio da experiência e do quarto fechado. Este agora é o âmbito de operações abstratas composta pelas interpretações - ou pelas versões - que conformam a "realidade", em geral definida por um relato oficial. Pensemos no Estado e seus agentes públicos que produzem não só uma versão, no caso para o assassinato do porto-riquenho, como também nos serviços secretos, na inteligência do Estado, que inventa "uma memória incerta e uma experiência impessoal". ${ }^{23}$

No livro, Alvo noturno, à medida que os relatos são apresentados, percebemos que aquilo que aparecia no início do romance não corresponde ao que de fato aconteceu. E a leitura nos envolve num jogo de aparência e realidade - que se dá principalmente entre duas grandes interpretações: o ponto de vista do promotor Cueto e o do delegado Croce. O promotor, cuja máxima é "as coisas que parecem diferentes na verdade são a mesma coisa", quer, sem qualquer investigação sobre o assassinato do forasteiro Tony Durán, logo apontar o assassino e o motivo para impedir que a investigação remonte toda a teia de interesses e pessoas ligadas ao assassinato.

O delegado Croce, ao contrário do promotor, está interessado em demonstrar "que as coisas que parecem a mesma coisa na verdade são diferentes". Eis seu lema: "Vou ensiná-los a ver as diferenças". E diante de um desenho (típico exemplo da psicologia gestáltica) no qual tanto se poder ver um pato como um coelho, dependendo do modo como se olha, afirma: "O que significa ver uma coisa tal como ela é: não é fácil”".

Croce, numa conversa com Renzi, explica a ideia do "ver como". Há sempre uma compreensão prévia ao ato de perceber, só podemos encontrar, por exemplo, o bicho que queremos caçar seguindo seus rastros se já sabemos qual é esse bicho. Assim, se sei que quero caçar uma raposa, posso identificar essas pegadas como sendo deste animal e não de outro. Só posso inferir a partir dos dados.

"Descobrir é ver de outro modo o que ninguém percebeu" diz o delegado, e continua, compreender "não é descobrir fatos nem extrair inferências lógicas, muito menos construir teorias, é simplesmente adotar o ponto de vista adequado para apreender a realidade". ${ }^{24}$

23 Idem. Formas breves. Barcelona: Editorial Anagrama, 2000, p. 51.

24 PIGLIA, R. Alvo noturno. São Paulo: Companhia das Letras, 2011, p. 123. 
Esse método do "ver-como" não é outra coisa senão o quadro conceitual que organiza e molda a experiência. Define-se primeiro se tal pessoa é culpada ou não culpada pelo assassinato e, a partir desse alvo, os dados são organizados. A briga entre o promotor e o delegado, portanto, se dá entre dois "ver-como", duas interpretações: o promotor incrimina um determinado personagem; ao passo que o delegado o vê como inocente.

7. Emilio Renzi, no romance Respiração Artificial, já aparece como escritor que, em 1976, havia publicado seu primeiro livro La prolijidad de lo real ${ }^{25}$, um romance que procurava reconstruir uma tragédia ocorrida em sua família. O tio Marcelo Maggi (único herói da família digno de ser lembrado, diz Renzi), irmão de sua mãe, casado com uma mulher rica, foge, após seis meses de casamento, com todo o dinheiro da esposa e com uma dançarina de cabaré.

Quando o livro é publicado, o tio Maggi manda para o sobrinho uma carta com uma foto em que aparecem o tio, o bebê Renzi e sua mãe. Atrás da foto ele anota a data (1941) e a seguinte frase: We had the experience but missed the meaning/and approach to the meaning restores the experience. T. S. Eliot. ${ }^{26}$

Os versos de Eliot - epígrafe do livro Respiração artificial - dimensiona toda a discussão entranhada no livro: experiência e sentido. Passados três anos da publicação de seu primeiro livro, Renzi ainda gosta do título do livro e da reação do tio, pois é a carta do tio que o impulsiona a começar outro livro - justamente Respiração artificial cuja abertura é uma interrogação: “Dá uma história?”(“¿Hay una historia?”). O livro é a tentativa de responder à pergunta, o que transforma o romance numa incessante indagação acerca dos procedimentos narrativos históricos e ficcionais. Como narrar? Como narrar fatos reais? (O próprio tio, que agora vive como professor recolhido no interior da Argentina, está interessado em mostrar o movimento histórico na vida excêntrica de Enrique Ossorio, que havia sido secretário particular de Juan Manuel de Rosas.)

25 O título é o último verso de uma poema de Jorge Luis Borges, "La noche que en el sur lo velaron", do livro Cuaderno San Martín (1929).

26 "Tivemos a experiência mas perdemos o sentido/e a aproximação ao sentido restabelece a experiência". 
Dividido em duas grandes partes, que contêm outras quatro - cada qual narrada de um modo: cartas, conversa, leitura de diário e conversa -, o livro também circunscreve a questão do desaparecimento da experiência:

[...] no fundo nada de extraordinário pode acontecer conosco, nada que valha a pena contar. Quero dizer que, na realidade, é fato que nunca acontece nada conosco. Todos os acontecimentos que podemos contar sobre nós mesmos não passam de manias. Porque em suma o que podemos chegar a ter na vida salvo duas ou três experiências? Duas ou três experiências, não mais que isso (às vezes, inclusive, nem isso). Já não há experiências (no século XIX havia?), só ilusões. Nós todos inventamos variadas histórias para nós mesmo (que no fundo são sempre a mesma) para imaginar que aconteceu alguma coisa conosco na vida. $^{27}$

Em outra carta, Maggi retoma uma observação de seu amigo Tardewski - um filósofo polonês que veio parar na Argentina, seu parceiro de xadrez - que dizia que a natureza não existe mais. Sua existência ainda podia ser constatada, ou nas catástrofes naturais, ou na lírica. Estamos rodeados pelo artifício, tudo leva a marca do homem. Segundo o filósofo polonês, no relato que faz do encontro com Renzi, este está convencido de que não há mais experiências, nem aventuras. Só paródias. Onde antes havia acontecimentos, experiências, paixões, hoje só restam paródias. ${ }^{28}$

O tio, no entanto, salienta que não "devemos desconfiar, por outro lado, da resistência do real ou de sua opacidade. A pomba que sente a resistência do ar, diz meu amigo Tardewski citando Kant, a pomba que sente a resistência do ar pensa que poderia voar melhor no vácuo". ${ }^{29}$

A imagem da pomba aparece na introdução à Crítica da Razão Pura, de Kant, em 1781, livro em que o filósofo de Königsberg opera uma crítica radical à metafísica uma "ciência" que até então não havia examinado seus fundamentos e, tal como a pomba, preferiria voar no vácuo para não enfrentar qualquer resistência. Ou seja, a metafísica levava seus conceitos e ideias para longe da experiência e falava de objetos

27 PIGLIA, R. Respiração artificial, São Paulo: Iluminuras, 1987, pp. 30-1.

28 PIGLIA, R. Respiração artificial, São Paulo: Iluminuras, 1987, pp. 28 e 103.

29 Idem, ibidem, p. 28. 
que não passavam de pura quimera. $\mathrm{O}$ esforço kantiano seria, então, não deixar que conceitos e ideias vagassem no espaço vazio, mas mostrar como devem ser aplicados ao domínio da experiência. ${ }^{30}$

Esse gesto kantiano, num certo sentido, também inaugura o tempo do fim da experiência, porque esta não é algo que nos acomete, mas sim o resultado de uma construção, portanto artifício, feita pelo uso conjunto das faculdades da sensibilidade (intuições) e do entendimento (conceitos). Nesse sentido, Renzi pode afirmar que "já não há experiência" porque já não há mais acontecimentos. Afastado da natureza e rodeado pelo artificial, o homem se encontra destituído do real e preso a uma cadeia de interpretações e explicações, o que impede que a vida produza um acontecimento. Nada marca o coração do homem. É assim que Renzi interpreta o episódio do homem louco que sequestrou um amigo do tio e quase o matou. Quando o sequestrado é libertado, sai do banheiro e diz: "finalmente me aconteceu algo". $\mathrm{Na}$ impossibilidade de um acontecimento - que inauguraria o tempo da experiência -, resta preencher o vazio com ilusões. Nossa vida não passaria, então, de relatos que inventamos para nós mesmos.

Respiração artificial encerra um paradoxo: ao mesmo tempo em que toda a discussão do livro é sobre o fim da experiência e da narração (a história pacifica o sentido da experiência, a informação pulveriza o sentido), o livro utiliza como procedimento narrativo as formas em que a experiência singular pode ser abrigada e narrada: carta, diários, diálogos. O que a investigação levada a cabo no livro nos mostra é que o vazio da experiência foi coberto por diversos relatos - de vozes e lugares distintos - e cabe ao narrador-leitor apenas dar voz a essa multiplicidade de sentidos.

8. Mas antes de alcançar essa posição, Emilio Renzi vaga em busca do lugar do narrador. Nas páginas finais do livro Alvo Noturno, ele, depois de jantar, conversando com os amigos numa varanda que dava para o rio, teve a sensação de que o:

delta era uma parte ainda não compreendida da realidade, como fora aquele povoado rural onde passara algumas semanas, uma espécie de momento arcaico em sua vida de homem da cidade, incapaz de compreender aquela volta à natureza, embora nunca deixasse de

$30 \mathrm{Na}$ desordem inaugurada pela ausência de Deus e da Natureza, pano de fundo sob o qual a filosofia kantiana é "construída", o projeto crítico de Kant de constituição e formação da experiência, ou seja, dar ordem à multiplicidade sensível por meio das faculdades humanas, já não assinalaria o fim da experiência? 
imaginar um retiro drástico que o levasse a um lugar afastado e tranquilo onde pudesse dedicar-se ao que Emilio - como Luca também imaginava que fosse seu destino. ${ }^{31}$

Luca Belladona não só tinha construído uma fábrica no deserto argentino junto com o irmão, como também, após a derrocada, passara a viver dentro de seu invento, anotando a lembrança de seus sonhos nas paredes a fim de perceber numa série de sonhos determinados conteúdos que eram constantes. No fundo, recolhia os sentidos possíveis de sua vida. Mas o maior esforço despendido por ele foi na construção de um objeto cônico de seis metros de altura parecido com "uma pirâmide pré-histórica" ou com "um protótipo da máquina do tempo", denominado mirante ${ }^{32}$, que oferecia uma vista magnífica e circular.

Para Renzi, tanto a imagem do retiro quanto a do mirante são a constatação daquilo que ele como escritor (em Alvo noturno, já tinha publicado um livro de contos) ainda não encontrara: um lugar a partir do qual fosse possível narrar. Na obra de Piglia, Luca Belladona encarna o protótipo do narrador, assim como Steve Ratliff em "Prisão Perpétua", ou como o tio Maggi e o polaco Tardewsky em Respiração artificial, ou a máquina de Macedonio em $A$ cidade ausente. Todos eles são aquilo que Ratliff havia sido para o jovem Piglia que começara a escrever: a paixão pura do relato. ${ }^{33}$

Esses narradores são os substitutos dos marinheiros, mas eles não pertencem mais ao rio da experiência, pois foram expelidos para os limites ou bordas da linguagem. É curioso notar que todos eles carregam uma experiência de ausência (a perda da fábrica, da mulher amada, da pátria, da cidade natal), como se a falta os destacasse do mundo e, deslocados, pudessem se dedicar aos artifícios por meio dos quais a narração fosse possível.

O que esses personagens tornaram possível foi a constituição de um gênero em resposta à falta de experiência. O próprio Renzi alude a essa possibilidade:

A investigação não tem fim, não pode terminar. Seria preciso inventar um novo gênero policial, a ficção paranoica. Todos são suspeitos,

31 PIGLIA, R. Alvo noturno. São Paulo: Companhia das Letras, 2011, p. 254.

32 Idem, ibidem, p. 219.

33 PIGLIA, R. Prisão perpétua. São Paulo: Iluminuras, 1989, p. 45. 
todos se sentem perseguidos. $\mathrm{O}$ criminoso não é mais um indivíduo isolado, mas uma quadrilha com poder absoluto. Ninguém entende o que está acontecendo; as pistas e os testemunhos são contraditórios e mantêm as suspeitas em aberto, como se mudassem a cada interpretação. ${ }^{34}$

A ficção paranoica pode ser caracterizada, por um lado, pela subjetividade que se sente ameaçada por inimigos, complôs, conspirações, o estranho que não faz parte de sua comunidade, enfim, por tudo aquilo que uma consciência paranoica "cria" e, por outro, pelo delírio interpretativo, que é a tentativa de encontrar uma causa para tudo aquilo que acontece.

9. Walter Benjamin identificou a crise da experiência - e suas perdas correlatas (memória, sabedoria, oralidade) - a partir do impacto técnico causado pela invenção da imprensa que alterou o modo de "captação do vivido", pois o acontecimento não mais estava a serviço da narrativa, mas da informação. ${ }^{35}$

Num ensaio sobre Borges, Piglia mostra que os grandes relatos borgianos tratam da incerteza da memória pessoal, da vida perdida e da experiência artificial. Para ele, isso põe Borges no centro da narrativa contemporânea (o mesmo tema aparece em W. Burroughs, T. Pynchon, P. Dick), em que vemos a destruição da memória pessoal, ou melhor, a substituição da memória própria por uma cadeia de sequências e de recordações estranhas, segundo Piglia. Mais importante nesse universo é a manipulação da memória e da identidade. ${ }^{36}$

Essa manipulação pode ocorrer por meio da informação. Ela substitui o vazio da experiência pessoal por uma experiência impessoal, garantia de um sentido unívoco. É como se o Estado, através de seus aparatos de inteligência, produzisse uma experiência e uma memória a fim de construir uma realidade. Em resposta a isso, a obra de Piglia realiza dois movimentos de resistência: no primeiro, a literatura se opõe ao relato oficial, ou seja, ao Estado, que por meio de suas instituições pretende difundir e impor seu relato como realidade ou verdade.

34 Idem. Alvo noturno, São Paulo: Companhia das Letras, 2011, p. 243.

35 BENJAMIN, W. "O narrador". In: Magia e técnica, arte e politica. Obras Escolhidas, vol. 1. São Paulo: Brasiliense, 1987, p. 203.

36 PIGLIA, R. Formas breves. Barcelona: Editorial Anagrama, 2000, pp. 47-54. 
No conto "A louca e o relato do crime", encontramos a contraposição entre "relato oficial" e "contrarrelato". O jornalista Renzi é proibido de fazer uma matéria para o jornal sobre a morte de uma prostituta, que havia sido assassinada por seu cafetão. ( $O$ leitor já sabe quem é o assassino, porque o conto começa com o relato do crime.) Três envolvidos. A única testemunha é uma mendiga louca, cujo depoimento provaria a inocência daquele que fora acusado pela polícia.

Por meio de procedimentos meramente linguísticos, Renzi descobre quem é o assassino, mas Luna, seu chefe na redação do jornal, o proíbe de publicar a matéria no jornal, ou mesmo mandá-la ao juiz, porque não quer problemas com a polícia. "Se eles [a polícia] dizem que foi a Virgem Maria que o matou, você escreve que foi a Virgem Maria que o matou", diz Luna. ${ }^{37} \mathrm{O}$ que Renzi quer é o restabelecimento da verdade do ocorrido para preservar a inocência. Proibido de publicar a matéria, Renzi decide então escrever um relato, que o leitor está lendo.

10. Ao deslocar a questão da verdade para o âmbito da ficção ${ }^{38}$, Renzi ecoa um gesto inscrito nas origens da literatura argentina, na tradição inaugurada por Domingo $\mathrm{F}$. Sarmiento, cujo exemplo mais marcante é o escritor e jornalista argentino, Rodolfo Walsh. O Estado sempre aparece como interdição ou proibição da verdade: se o jornalista é proibido de denunciar e trazer à tona certa verdade, o escritor entra em cena; se o escritor é proibido de fabular (e aqui também podemos pensar numa interdição interna, ou seja, a forma ficcional não dá conta do problema), o jornalista entra em cena para apresentar a verdade material. Nos dois casos, o que importa é determinar "onde está a verdade, atuar como um detetive, descobrir o segredo que o Estado manipula, revelar essa verdade que está escamoteada". ${ }^{39}$

O segundo movimento é a questão do reposicionamento do narrador. Com o fim da experiência, qual é o lugar do narrador? No conto, "Um peixe no gelo", escrito no início da década de 1970, e incorporado ao livro "A invasão" somente na nova edição ${ }^{40}$,

37 Idem. Prisão perpétua. São Paulo: Iluminuras, 1989, p. 124.

38 Há uma passagem do livro Prisão perpétua (p. 20) que sintetiza essa questão: "Narrar, dizia meu pai [o pai de Steve Ratliff], é como jogar pôquer, todo segredo consiste em parecer mentiroso quando se está dizendo a verdade".

39 PIGLIA, R. Tres propuestas para el próximo milênio (y cinco dificultades). Buenos Aires: Fondo de Cultura Economica, 2001, p. 21.

40 Idem. La invasión, Barcelona: Editorial Anagrama, 2006, pp. 175-94. 
Renzi, motivado por uma bolsa para estudar a obra de Pavese e para esquecer uma mulher, viaja a Turim. Lendo os diários de Pavese, O oficio de viver, Renzi se dá conta de que o diário começava e terminava com duas grandes crises. As mulheres eram o pretexto. A descoberta o leva a relacionar em vários escritores a relação entre a escrita, a mulher e a morte.

Um deles é Franz Kafka, de quem Renzi havia anotado em seus cadernos: aquele que não conseguiu estabelecer nenhum acordo com a vida, precisa afugentar com uma das mãos o desespero que lhe causa o destino e com a outra anotar o que vê, pois vai ver coisas que ninguém vê justamente porque é um morto em vida, é um sobrevivente real. ${ }^{41}$ O narrador emenda essa questão da posição do narrador com o conto de Kafka "O caçador Graco", sobre um caçador que morreu, mas que num certo sentido também está vivo. Ou seja, não foi para o reino dos mortos, mas também não pertence mais ao reino dos vivos, tornou-se um habitante, um errante, das regiões inferiores da morte. Segundo Piglia, na obra de Kafka encontramos dois tipos de narrador: aquele que não entende as conexões que vê; e aquele que entende as conexões que ninguém vê. Nos dois casos, o narrador encontra-se deslocado.

Há um aforismo de Kafka, o de número 27, que contribui ao esclarecimento dessa questão. Ele diz assim: "Ainda estamos compelidos a realizar o negativo; o positivo já nos foi concedido". ${ }^{42} \mathrm{O}$ positivo pode ser lido como o excesso de informação e de relatos oficias ao qual estamos submetidos, como se estivéssemos trancafiados dentro de um espaço moldado por esses discursos, que por codificarem, ou determinarem, toda experiência vedam a possibilidade de uma experiência nua, aberta, indeterminada. Ser convocado a realizar o negativo seria então abrir uma brecha por onde o narrador escaparia da positividade, ganharia distância e teria assim um lugar onde pudesse começar a narrar.

Essa busca pelo retiro, onde se possa exercer o ato da escrita, reaparece numa carta de Kafka a Felice Bauer. ${ }^{43}$ A imagem que Kafka faz do ato da escrita é a de um homem de pijamas, enfiado numa caverna, isolado, recebendo, de quando em quando,

41 Idem, ibidem, p. 184.

42 KAFKA, F. Beim Bau der chinesischen Mauer und andere Schriften aus dem Nachlaß. Beim Bau der chinesischen Mauer und andere Schriften aus dem Nachlaß. Frankfurt am Main: Fischer Taschenbuch Verlag, 2008, p. 232.

43 PIGLIA, R. El último lector, Barcelona: Editorial Anagrama, 2005, p. 43. 
comida por uma portinhola e todo o tempo concentrado na escrita, sem qualquer interrupção.

A obra de Kafka parece mostrar e prefigurar essa questão da busca pelo "lugar do narrador": sair do positivo e realizar o negativo.

11. "Não se escreve para recordar", dizia Kafka, "mas para fazer ver”. Não se trata aqui de forjar mais um "ver como", uma nova perspectiva, acerca de um determinado acontecimento. Ao contrário, "fazer ver" funciona como um mirante a partir do qual se avista a multiplicidade de sentidos por meio dos quais se pode alcançar a experiência desaparecida.

O mirante encontra sua definição naquilo que o personagem Luca pensa sobre o imaginário: não é o irreal, mas sim o possível, o que ainda não existe, e nessa projeção para o futuro está, ao mesmo tempo, o que existe e o que não existe. Esses dois polos se intercambiam continuamente. E o imaginário é esse intercâmbio. "O real", escreve Piglia, "não é o objeto da representação mas o espaço em que um mundo fantástico acontece". ${ }^{44}$

Que essa afirmação de Piglia não seja interpretada como se tudo fosse ficção. Vale para a obra desse autor argentino aquilo que ele escreveu sobre seu compatriota Rodolfo Walsh: uma coisa é deslocar o uso da ficção, outra é considerar tudo como ficção. Não seria possível tornar tudo ficção, porque no centro da obra há um desaparecimento, uma morte, o cadáver da experiência impedindo que a realidade seja apagada por qualquer tipo de discurso. A morte funciona como um "alvo noturno" que guia a busca do leitor.

A morte, o mistério, o vazio tornam tensa a relação entre o verdadeiro e o falso no âmbito da ficção. A concepção de verdade atrelada ao verificável não interessa à ficção, já que, como escreveu Saer no ensaio $O$ conceito de ficção, nenhum livro é escrito tendo uma realidade prefigurada à qual o livro deva corresponder, muito menos para ser uma apologia do falso como simples oposição à verdade verificável. Em Piglia, a verdade tem a ver com o olhar, como assinala um de seus personagens (a verdade "não passa de um artefato microscópico que serve para medir com precisão milimétrica a ordem do mundo"45), e com a dificuldade de ser escrita.

44 PIGLIA, R. El último lector, Barcelona: Editorial Anagrama, 2005, p. 12.

45 Idem. Prisión perpetua. Barcelona: Editorial Anagrama, 2007, p. 82. 
Sua obra nos faz ver uma tensão de outra ordem: entre o inconsciente (fonte de experiências perdidas) e a percepção domada (o espaço prefigurado pela informação ou relatos objetivos). Num ensaio sobre as relações entre psicanálise e literatura, Piglia, recordando o escritor argentino Manuel Puig, escreveu que o inconsciente está estruturado como folhetim e que na crise da experiência atual a psicanálise e a literatura nos ajudam a sermos detetives de nós mesmos para encontrarmos nossa dramaticidade profunda. Nem que esta seja a constatação do vazio da experiência e do isolamento em relação à vida. ${ }^{46}$

A literatura teria então uma dupla tarefa: por um lado, ela preservaria a fonte inesgotável de relatos - o que mantém a singularidade dos acontecimentos humanos -; por outro, a leitura traria à tona a experiência esquecida e "desdomesticaria" a percepção.

12. "A leitura é a arte de construir", escreve Piglia, "uma memória pessoal a partir de experiências e lembranças alheias". ${ }^{47}$ Ela devolve nossa experiência perdida quer por meio do bovarismo (minha vida é vazia, então leio para viver aquilo que leio), quer pelo bovarismo invertido (leio minha própria história no livro, o que leio é o meu destino), ou então no exemplo de Robinson Crusoe: foi pela leitura que ele, perdido numa ilha, reconstruiu o real perdido. A leitura não só nos faz ver em escala reduzida o real, como é também uma "forma privada de utopia". 48

Num ensaio sobre Joyce, do livro $O$ último leitor, Piglia escreve que o gênio irlandês teria deslocado a posição do narrador para o âmbito do leitor. Este cumpre agora a função ordenadora do narrador e sabe "mais que o narrador e é capaz de decifrar todos os sentidos"49 - um leitor perfeito, portanto. A leitura é também o novo local do narrador.

De Kafka, sai a ideia do narrador que se destaca da positividade do excesso de significação e se mantém em deslocamento continuo; de Joyce, a ideia do leitor como narrador. Nos dois casos, esse gesto só é possível por aqueles que se trasladaram para os limites do sentido ou viveram uma experiência extrema.

46 Idem. Formas breves. Barcelona: Editorial Anagrama, 2000, p. 59.

47 PIGLIA, R. Formas breves. Barcelona: Editorial Anagrama, 2000, p. 53.

48 Idem. Prisão perpétua. São Paulo: Iluminuras, 1989, p. 13.

49 Idem. O último leitor. São Paulo: Companhia das Letras, 2006, p.178. 
13. "A ausência é uma realidade material como o poço no pasto", teria dito Macedonio que, no romance $A$ cidade ausente, por se encontrar inteiramente destroçado pela morte da mulher, Elena, concebe uma máquina narrativa (uma Scherazade artificial que concentra todo o universo) para substituí-la. Para Piglia, a ausência da cidade natal também é uma realidade material que o empurrou para a escrita. A máquina literária de Piglia, como a de Macedonio, são inventos produzidos pelo homem para que a linguagem continue jorrando os múltiplos sentidos das futuras experiências:

[...] há uma torneira ali no jardim, quase à altura do chão, que puxa uma água fresca, mesmo em pleno verão, fica junto à cerca de alfenas e eu às vezes imagino que me deito na grama para beber dali, mas eu nunca faço isso e desse modo mantenho viva a possibilidade, entende, uma forma disponível, essa é a lógica da experiência, sempre o possível, o que está por vir, uma rua no futuro, uma porta entreaberta numa pensão perto de Tribunales e o tanger de um violão. ${ }^{50}$

14. Num diálogo com o escritor Juan Villoro, Piglia mencionou uma cena de sua infância: aos quatro anos de idade, em Adrogué, ele viu o pai lendo um livro sentado na poltrona. Retirou então um livro de capa azul da biblioteca do pai, dirigiu-se à porta da casa e se sentou na soleira. A rua era uma rua tranquila, perturbada apenas pelos transeuntes que, a cada meia hora, passavam diante da casa, vindos da estação de trem, localizada perto dali. Sentado na soleira para que o vissem lendo, um passageiro passou e disse que o livro estava de ponta-cabeça. Anos depois, ele perguntaria ao pai que livro seria aquele, e seu pai, ironicamente, respondeu: "quem sabe o livro azul do peronismo". 51

Essa cena, mais aquela do ponto de partida de sua relação com a linguagem (refiro-me aqui quando Piglia começou a escrever seu Diário, também em Adrogué), funcionam, juntas, como inscrições de origem, experiências pessoais que definem

50 PIGLIA, R. A cidade ausente. São Paulo: Iluminuras, 1997, p.114.

51 Em fevereiro de 1946, o governo dos EUA editou um livro, denominado "Livro Azul", a partir do memorando preparado pelo ex-embaixador dos EUA em Buenos Aires, Spruille Braden, em que constavam sérias acusações contra o então candidato Juan Domingo Perón. A intenção da publicação era a reputação do candidato, vinculando, por exemplo, o nacionalismo argentino (representado por Perón) ao nazismo. 
aquilo que o filósofo alemão Peter Sloterdijk chamou de tatuagem ontológica, ou seja, a marca inscrita no corpo do escritor muito antes de ele ter escrito qualquer linha. Nelas estão condensadas duas feições da obra de Ricardo Piglia: o diário que funciona como trincheira: afasta a realidade e possibilita a seu autor a formação de uma utopia privada; e a leitura, que aparece na postura do menino que lê o livro, segurando-o de pontacabeça, sentado na soleira da porta da casa: a leitura não só define uma separação entre o espaço público e privado, mas também um leitor que "aspira ao isolamento e à intimidade" e à experiência singular.

15. O inquérito da dupla Piglia-Renzi produziu então o seguinte informe: constatado o desaparecimento da experiência, a narrativa ganha o abrigo de um novo gênero - a ficção paranoica. Nela o narrador passa a ocupar duas posições: a de construtor de uma máquina sinóptica que torna visível uma diversidade e multiplicidade de relatos; e a de um investigador que busca e decifra os sentidos dos relatos que cada um cria para si mesmo. As duas mutações acabam por transformar o narrador num leitor que percorre uma rua de mão única: dos sentidos às experiências.

\section{Referências Bibliográficas}

\section{Obras de Ricardo Piglia}

Original

Piglia, Ricardo. La invasión. Barcelona, Editorial Anagrama, 2006.

-. Nombre falso. Barcelona, Editorial Anagrama, 2002.

-. Prisión perpetua. Barcelona, Editorial Anagrama, 2007.

-. Respiración artificial. Barcelona, Editorial Anagrama, 2001.

-. La ciudad ausente. Barcelona, Editorial Anagrama, 2003.

-. Plata quemada. Terceira edição “Compactos”, Barcelona, Editorial Anagrama, 2011.

-. El último lector. Barcelona, Editorial Anagrama, 2005.

-. Blanco nocturno. Barcelona, Editorial Anagrama, 2010.

-. Formas breves. Barcelona, Editorial Anagrama, 2000.

-. Crítica y ficción. Buenos Aires, Seix Barral, 2000. 
-. Tres propuestas para el próximo milênio (y cinco dificultades). Buenos Aires, Fondo de Cultura Economica, 2001.

-. La ficción paranoica. Clarín, 10/10/1991.

-. "La experiência artística es una pausa en la lógica de la realidad" (Entrevista por Gastón Garcia), Letras Libres, março 2011, p. 70-73.

-. "Escribir es conversar" (Diálogo Ricardo Piglia y Juan Villoro), Letras Libres, setembro 2007, p. 48-55.

\section{Traduzidas:}

Piglia, Ricardo. A invasão. Tradução de Rubia Prates Goldoni e Sérgio Molina. São Paulo, Iluminuras, 1997.

-. Nome falso. Tradução de Heloisa Jahn. São Paulo, Iluminuras, 1988.

-. Prisão perpétua. Tradução de Rubia Prates Goldoni e Sérgio Molina. São Paulo, Iluminuras, 1989.

-. Respiração artificial. Tradução de Heloisa Jahn. São Paulo, Iluminuras, 1987.

-. O laboratório do escritor. Tradução de Josely Vianna Baptista. São Paulo, Iluminuras, 1994.

-. A cidade ausente. Tradução de Sérgio Molina. São Paulo, Iluminuras, 1997.

-. Dinheiro queimado. Tradução de Rosa Freire D’Aguiar. São Paulo, Companhia das Letras, 1998.

- O último leitor. Tradução de Heloisa Jahn. São Paulo, Companhia das Letras, 2006.

-. Alvo noturno. Tradução de Heloisa Jahn. São Paulo, Companhia das Letras, 2011.

-. "Teoria do complô", Serrote 2, julho, 2009, p. 96-111.

-. "Sarmiento, escritor”. In: Facundo ou civilização e barbárie. Tradução e notas de Sergio Alcides. São Paulo, Cosac Naify, 2010, p. 9-41.

\section{Outras obras}


Benjamin, Walter. Magia e técnica, arte e política. Obras Escolhidas, vol. 1. Tradução de Sérgio Paulo Rouanet. São Paulo, Brasiliense, 1987.

Kafka, Franz. Beim Bau der chinesischen Mauer und andere Schriften aus dem Nachlaß. Fischer Taschenbuch Verlag, Frankfurt am Main, 2008.

Saer, Juan José. El concepto de ficción. Buenos Aires, Seix Barral, 2004.

Schwartz, Adriano. "A tendência autobiográfica do romance contemporâneo", Novos Estudos 95, março 2013, p. 83-97.

-. "Biografia de uma ficção: o romance dentro do romance em Respiração artificial, de Ricardo Piglia”, Revista USP, n. ${ }^{\circ}$ 97, março/abril/maio 2013, p. 82-91.

Sloterdijk, Peter. Venir al mundo, venir al lenguaje (Lecciones de Frankfurt). Tradução de Germán Cano. Pre-textos, Valencia, 2006.

Villoro, Juan. Piglia, private eye. Letras Libres, Maio, 2005. 